\title{
An Exploratory Analysis of the Effects of the Ownership Concentration on the Chinese State-owned enterprises of the Electric Power Industry
}

\author{
Dai Li-xin ${ }^{1, a}$, Chen Ying ${ }^{2, b}$ and Cui Zhan-peng ${ }^{3, c}$ \\ ${ }^{1}$ Department of Economics \& Management, North China Electric Power University, Baoding City, \\ Hebei Province, China \\ ${ }^{2}$ Department of Economics \& Management, North China Electric Power University, Baoding City, \\ Hebei Province, China \\ ${ }^{3}$ Department of Economics \& Management, North China Electric Power University, Baoding City, \\ Hebei Province, China \\ adlx1966@163.com, b987078379@qq.com, c273514390@qq.com
}

Keywords: Equity concentration, dividend policy, the power industry

\begin{abstract}
In recent years, due to the continuous improvement of the capital markets, dividend policy as an important factor is becoming more and more important for the vast number of investors, shareholders and enterprise operators. The signal that different dividend polices convened is different. In the company's actual operation process, the choice of the dividend policy will be affected by many aspects, such as the company's future financing needs, current operating conditions and ownership concentration. But in our country, due to the influence of the policy, as well as the particularity of state-owned listed companies, the dividend policy selection has difference with other enterprises. In this paper, we will use the power's data of listed companies as samples.
\end{abstract}

\section{Introduction}

When select dividend policy suited to the enterprise development, a number of factors must be taken into consideration. For example, the company's financing needs, the company needs to bear the social responsibility, etc. Educational world and the industry has always been very concerned about the dividend distribution of listed companies, because it is directly related to the interests of shareholders and stakeholders, although different countries have different physical background, the influence of dividend distribution problems show individual differences. But, no matter how system and legal environment of the listed company ownership structure must be one of the key factors affecting the dividend policy. Current dividend policy of listed company is likely to affect the shareholders of a company's current earnings, and the dividend policy selection, and will have great influence on future development of the company, in relation to the operator and the equilibrium relationship between the groups of shareholders. Over the years of the scholars' study found that the equity structure of listed companies has a significant effect on dividend policy, especially the cash dividend policy.

\section{Literature review}

Research in the field of dividend distribution policy has shown the advantage of scholars' analysis of corporate behavior or helped joint stock company managers to make decisions. This paper discusses the influence factors of dividend distribution policy. Global experience makes clear the importance of dividend policy as a promoter in large corporations (Livoreka, 2014). Hetemi (2014) and Shala (2014) consider corporations as the back bone of the economy and a key source of jobs and certainly the largest taxpayer of an economy. So, study of dividend distribution policy is very important to enterprise.

Furthermore, studies on dividend policy divide the policy into the following kinds, cash dividend, stock dividend and stock repurchase. Primarily, research on dividend policy has focused on the 
selection of optimal dividend policy that is one of the main questions in the company's financial management strategy (Aleknevicine ,2006; Domeika,2006).In recent years it appeared that most common way of distribution in global corporations was cash dividend (Shala,2014).Then, Jing Feng and Ming Zhou(2011) put forward the risk control of dividend policy. Now, growing number of scholars began to study the influence factors of dividend policy. Lopez-Iturriage and Santana-Martin examined the effect of shareholder coalitions on the corporate payout policy in Spain, a context characterized by the presence of dominant shareholders. And, they find that shareholder coalitions affect payout policy negatively and the divergence between the voting rights involved in the coalition and the dominant owner's voting rights is negatively related to dividends. Similarly, Ben-Nasr,H(2015) has researched the relationship between government ownership and dividend policy. Then, Wang Yuxi has showed that ownership concentration has a significant positive correlation to dividend payment.

This paper will study the situation of the Chinese market. Firstly, the paper considers ownership concentration as the independent variables to study how to affect the dividend policy of state-owned companies. In the end, the above results can be analyzed to obtain the paper's conclusions.

\section{Method}

In the study of this problem, the paper selected the industry with the strong characteristics of state-owned holding. Electric power is one of the basic industries of the country. The power industry is analyzed more representative sample. The CCER provides the number of listed companies and on the basis of industry classification standard, 52 a-shares in Shanghai and Shenzhen two cities electric power listed companies as research samples. The data in 2015 to 2016 was unable to get, so choose the data of 2014 as the main research sample. Sample to cut out the special nature of the electric power listed company, including ST companies as well as the data is not complete and audit issue a qualified opinion, the last remaining 47 companies as the research sample.

Electric power industry, based on this article selects hypothesis, is the higher ownership concentration. The company is more inclined to distribute cash dividends, and ownership concentration and the level of cash dividend payment have positive correlation.

This article selects samples for 48 a-share listed power company. Can be seen from table 1, 78.72\% are cash dividend. There are 10 don't send bonus enterprise, not to find gold, do not turn add equity and accounted for $21.28 \%$ of the total sample. According to the annual report of the 10 companies, they are all no profit.

Table 1 Dividend policy TAB

\begin{tabular}{c|c|c}
\hline Dividend policy & quantity & proportion \\
\hline Cash dividends. & 37 & $78.72 \%$ \\
\hline Don't distribute & 10 & $21.28 \%$ \\
\hline Stock dividend. & 0 & $0 \%$ \\
\hline summation & 47 & $100 \%$ \\
\hline
\end{tabular}

There are many differences between Stock dividend and cash dividends. The pay of stock dividends is higher, and the company needs to pay fees and stamp duty. And compared with the stock dividend, cash dividend payments, costs less. But at the same time, there is more working capital outflow. According to the characteristics of the electric power industry companies, the reason of electricity companies chooses the cash dividend are as follow. They can give back to the shareholders. And most of the electric power enterprises have the support of the country, and as the country's basic industry, running mature, stable earnings, and there will be no other good investment motive of the project, to boost the share price will tend to distribute cash dividends.

From this table can also get the conclusion that for the electric power industry, whatever its shareholding structure, all profit companies choose cash dividend policy, the difference is that pay for different levels of cash dividend.

Next to the sample of the company's cash dividend payment levels (cash dividend payment rate) 
descriptive statistics analysis.

Table 2 the cash dividend descriptive statistics of the power industry

\begin{tabular}{c|c|c|c|c}
\hline Produce & Sample & Maximum & Minimum & Average \\
\hline All & 47 & 0.745 & 0 & 0.148 \\
\hline $\begin{array}{c}\text { The samples with } \\
\text { distribute }\end{array}$ & 37 & 0.745 & 0.017 & 0.19 \\
\hline
\end{tabular}

Table 3 the table of cash dividend status

\begin{tabular}{l|l|l}
\hline Dividend payment rate & Sample & proportion \\
\hline 0 & 10 & $27.03 \%$ \\
\hline $0-0.2$ & 23 & $48.94 \%$ \\
\hline $0.2-0.5$ & 12 & $25.53 \%$ \\
\hline $0.5-1$ & 2 & $4.26 \%$ \\
\hline
\end{tabular}

From the above statistics, we can find many things. Firstly, the power industry exclude this year profit is negative, namely red or enterprise accumulated undistributed profit is negative, the other companies prefer to choose cash dividend. Second, the power industry level of cash dividend payment relatively concentrated between $0-0.2$, compared with other industries, the power industry of the dividend payment rate in a low level.

\section{Variable Selection}

(1) The dependent variable as the explained variable is cash dividend payment level. It is the dividend distribution index. Index of dividend distribution include absolute and relative. Absolute index is per share cash dividend payments; Relative indicators are dividend payment rate that said value accounts for the proportion of earnings per share. Dividend per share reflects the size of the company's dividend payment. Because the absolute value is not comparable, different companies will have their own different situation. Between the per share cash dividend payments and cannot reflect the state of relatively comparable, so this article USES the absolute value is analyzed, the index for the data between different companies, has directly comparable.

(2) The independent variable is the explained variable. Ownership concentration is the independent variable. The index proportions are the first big shareholder holds the second largest shareholder ownership and the top five shareholders' shareholding, the coefficient of the fender, namely shareholding proportion to the sum of the squares of the top five shareholders. Will appear after the stake square Matthew effect, the smaller the proportion of small, the greater the proportion of large, more can highlight the ownership concentration gap between different companies, and the index can distinguish difference shareholding ratio and same ownership of different ownership concentration. Specific variables are shown in the following table.

Table 4 variables defined

\begin{tabular}{c|c|c|c|c}
\hline Category & $\begin{array}{c}\text { Symboli } \\
\text { c }\end{array}$ & Name & Measure & $\begin{array}{c}\text { Relevanc } \\
\text { e }\end{array}$ \\
\hline \multirow{2}{*}{ Dependent } & DPS & Cash dividend payment rate & $\begin{array}{c}\text { Dividend } \\
\text { distribution }\end{array}$ & \\
\hline \multirow{2}{*}{ Variable } & $\mathrm{S}_{1}$ & The first big shareholder & \multirow{2}{*}{ Ownership } & related \\
\cline { 2 - 3 } \cline { 3 - 3 } & $\mathrm{S}_{2}$ & The second largest shareholder & related \\
\cline { 2 - 3 } & $\mathrm{S}_{3}$ & Top five shareholding of squares & & related \\
\hline
\end{tabular}

Put the electric power industry in 2014 DPS and equity structure index into the model respectively 
$\mathrm{DPS}=\beta_{0}+\beta_{1} \mathrm{~S}_{1}+\beta_{2} \mathrm{~S}_{2}+\beta_{3} \mathrm{~S}_{3}+\xi$

\section{Analys is}

We get the above data generation into the SPSS. 23. The following results are obtained.

Table 5

\begin{tabular}{l|c|c|c}
\hline \multicolumn{4}{|c}{ Variables Entered/ Removed } \\
\hline \multirow{3}{*}{ Model } & Variables & Variables & \\
& Entered & Removed & Method \\
\hline 1 & S3, S2, S1 & & Enter \\
\hline
\end{tabular}

a. Dependent Variable: DPS

b. All requested variables entered

Into the model is given in the table above and remove the variable information. It can be seen from the table that all three independent variables are into the model, the interpretation of the description in this paper, we assume that the variables are significant and have explanatory power.

Table 6

\begin{tabular}{l|c|r|l|c}
\hline \multicolumn{5}{c}{ Model Summary } \\
\hline $\begin{array}{l}\text { Mode } \\
1\end{array}$ & $\mathrm{R}$ & R Square & $\begin{array}{l}\text { Adjusted R } \\
\text { Square }\end{array}$ & $\begin{array}{l}\text { Std. Error of } \\
\text { the Estimate }\end{array}$ \\
\hline 1 & $.308^{\mathrm{a}}$ & .095 & .013 & .1488033 \\
\hline \multicolumn{5}{l}{} \\
\hline
\end{tabular}

Model is presented in table 7. The fitting effect of goodness of fit of the model coefficient is 0.308, reflecting has low correlation of linear relationship between the dependent variable and independent variable. The table also shows the $\mathrm{R}$ square and the $\mathrm{R}$ value of adjusted estimate standard errors.

Table 7

\begin{tabular}{|c|c|c|c|c|c|c|}
\hline \multicolumn{7}{|c|}{ ANOVA } \\
\hline \multicolumn{2}{|c|}{ Model } & $\begin{array}{l}\text { Sum of } \\
\text { Squares }\end{array}$ & df & $\begin{array}{l}\text { Mean } \\
\text { Square }\end{array}$ & $\mathrm{F}$ & Sig. \\
\hline \multirow[t]{3}{*}{1} & $\begin{array}{l}\text { Regre } \\
\text { ssion }\end{array}$ & .077 & 3 & .026 & 1.156 & $.341^{\mathrm{b}}$ \\
\hline & $\begin{array}{l}\text { Resid } \\
\text { ual }\end{array}$ & .731 & 33 & .022 & & \\
\hline & Total & .807 & 36 & & & \\
\hline \multicolumn{7}{|c|}{ a. Dependent Variable: DPS } \\
\hline \multicolumn{7}{|c|}{ b. Predictors,(Constant) S3, S2, S1 } \\
\hline
\end{tabular}

Table 7 is the ANOVA table, models of setting test F statistic value of 1.156, significant levels of $\mathrm{P}$ value is 0.341 , you can see, there is a certain relationship between the dependent variable and independent variables, but no significant correlation.

Table 8

\begin{tabular}{|c|c|c|c|c|c|c|}
\hline \multicolumn{7}{|c|}{ Coefficients } \\
\hline & & \multicolumn{2}{|c|}{ Not standardized } & $\begin{array}{l}\text { Standardized } \\
\text { Coefficients }\end{array}$ & \multirow[b]{2}{*}{$\mathrm{t}$} & \multirow[b]{2}{*}{ Sig. } \\
\hline \multicolumn{2}{|c|}{ Model } & $\mathrm{B}$ & Std. Error & Beta & & \\
\hline \multirow[t]{2}{*}{1} & (Constant) & .083 & .142 & & .581 & .565 \\
\hline & S1 & .000 & .007 & .056 & .069 & .945 \\
\hline
\end{tabular}




\begin{tabular}{l|l|r|r|r|r|r}
\hline S2 & .005 & .004 & .227 & 1.114 & .273 \\
\hline S3 & $2.338 E-5$ & .000 & .208 & .266 & .792 \\
\hline
\end{tabular}

a.: Dependent Variable: DPS

Table 9 for regression coefficient table and $\mathrm{T}$ value of significance test of variables, it can be seen that the three variables of $\mathrm{T}$ value are too small.

\section{Summary}

Through the above research, we can see that the power industry is generally cash dividend. But dividend payment rate is generally low. And it is usually higher ownership concentration of electric power industry. The first big shareholders holding are more than $50 \%$ or $48.15 \%$ of the total sample. Concluded that equity concentration on the relationship between cash dividend payment rate is between, but the relationship is not significant. When selecting dividend policy of the electric power industry, the main influence factors still need further research.

China is a socialist country. And the economic policy is the public ownership as the main body a variety of common development. And electric power as the basic industry of the country is also the lifeblood industries. They have to the state for a long time. These characteristics lead to many behavior of the power industry, such as the selection of dividend policy is not the same as the other enterprises. Electric power enterprises adopt the cause of the cash dividend, it is because the industry itself has particularity, according to the theory of signal transmission, need stable each year a certain amount of dividends to shareholders. This behavior can be passed to the stock market and investor's stability information. For shareholders to obtain the dividend income as the main purpose cash dividend can provide a stable source of income; have a stronger appeal to the shareholders. Also meet some requirements for stable income of the needs of institutional investors. Some institutional investors, such as insurance companies, retirement pension funds, etc., need to make sure that their investment has a steady income. And will choose to invest in electric power industry, generally have a lower risk for hope, the robustness of the investors. So, the power industry will choose cash dividend, but common dividend payment rate is low.

\section{References}

[1] Besnik Livoreka, Alban Hetemi, Albulena Shala, Arta Hoti, Rrustem Asllanaj (2014).Theories on

Dividend policy empirical research in joint stock companies in Kosovo. Proscenia Economics and Finance, vol.14

[2] Vilija Alekneviciene, Povilas Domeika, Dalia Jatkunaite (2006). The development of company Dividend policy in respect of profit distribution priorities. Engineering Economics, vol. 5. pp.17.

[3] Jingfeng Xu,Ming Zhou(2011). Optimal risk control and dividend distribution policies for a diffusion model with terminal value. Mathematical and Computer Modelling,2012, vol.56(7-8). pp,180-190

[4] Lopez-Iturriage, FJ, Santana-Martin,DJ (2015).Do shareholder coalitions modify the dominant owner's control? The impact on dividend policy.Corporate Governance-an International Review.2015 23(6) pp519-533

[5] Ben-Nasr,H(2015), Government ownership and dividend policy:Evidence from newly privatised firms.Journal of Business Finance \& Accounting,41,63-73

[6] Wang Yuexi, Sun Lingyu (2014) The empirical analysis of dividend distribution policy listed. The Financial Theory and Practice 3,136

[7] Yan Taihua, Gong Chunxia (2012) Influence factors and dividend allocation policy of listed 
companies: from2005 2010.The Capital Market 3,130-133

[8] Lv Changjiang, Zhang Haiping (2012).The listed company equity incentive plan for the impact of Dividend distribution policy.Management of the World,11,133-144

[9]DaiLi-Xin,CuiZhan-Peng,in:Research on the Evaluation of Baidu's Enterprise Value Based on D CF, Advances in Social Science Education and Humanities Research, ATLANTIS Press, 2015 